Journal of Research in Engineering and Applied Sciences

\title{
AN INTEGRATED DESIGN FOR ENSURING WATER SECURITY AT DEVASTHAL, INDIA
}

\author{
${ }^{1}$ Tarun Bangia \\ ${ }^{1}$ Engineer, Department of Mechanical Engineering, ARIES, Nainital, India \\ Email: $\left\{{ }^{1}\right.$ bangia@aries.res.in $\}$
}

\begin{abstract}
Devasthal site of Aryabhatta Research Institute of Observational Sciences (ARIES), Nainital in central Himalayas is well known for its geographical location and accommodates three telescopes with their associated infrastructure. Further, development of site is planned with various upcoming astronomical and atmospheric instruments in near future. An integrated design for ensuring water security at this fast emerging astronomical observatory is carried out to supplement its existing sole ground water resource. Devasthal site receives sufficient rainfall but most of the water runs off and goes unutilized due to steep slopes and absence of natural barriers. Rainwater harvesting is seen as the most viable and long term solution to meet water requirements at remote site due to lack of conventional water supply systems. A scheme of rooftop rainwater harvesting system utilizing one of the astronomical building is discussed in the paper to sustain water requirements. Management of harvested water for the three buildings will be carried out with smart systems based on Internet of Things (IoT). As a drive towards self-reliance, various proactive customized steps are planned for rejuvenating the existing water supply and to create alternate supply for meeting growing and emergency demands.
\end{abstract}

Key Words - Devasthal, Rainfall, Rainwater harvesting, Recharge, Rooftop, Telescope.

\section{Introduction}

Water is an essential irreplaceable constituent to support life on the Earth. Availability of water ensures supply of products and services that play a vital role in meeting human, animal and agricultural needs. Increase in water consumption due to various developmental works and rise in population is pressurizing existing water resources day by day and situation may deteriorate in future. Human activities are resulting in ecological imbalance which is increasing scarcity of fresh water on the Earth. Steep rise in extraction of ground water to meet demands of increasing population is fast declining ground water table. Distribution of water resources among various countries is also quite uneven and thus poses multiple challenges in meeting their demands. Both quality and quantity of water need attention in the fast changing land use scenario to develop sustainable systems. Expansion of water resources network and their efficient management using smart systems is required to meet future demands.

India is rich in water resources but has non-uniform distribution over the entire span of country. Uneven spatial and temporal rainfall distribution creates scarcity of water during both pre and post monsoon periods. Indian Himalayan region has sufficient water resources consisting of glaciers, springs, lakes, ponds etc. and also receives substantial rainfall. Rapid urbanization and infrastructure development is leading to decrease in water tables and biodiversity in Himalayan regions. Pollution of existing natural water resources is creating problem of safe drinking water. Natural protected springs in mountains are quite effective in supplying water through gravity employing distribution of pipes to nearby populated places. However, interference in natural recharge due to deforestation has led to drying of Himalayan springs [1]. As water regimes are changing so it is also affecting livelihood of people. Heavy monsoon rainfall is resulting in soil erosion, landslides and floods etc. Owing to good natural view from high mountain heights, many tourist places and houses etc. are built on hilltops with scarce water supplies. Increase in tourist activities and population growth have further added to water shortages in Himalayas despite receiving substantial annual rainfall. An estimate [2] indicated that total water flowing from Himalayas to plains is about $8.634 \times 10^{12} \mathrm{~m}^{3}$ per year. Runoff in Himalayas is maximum between altitudes of 1,500 to $3,500 \mathrm{~m} \mathrm{[3]} \mathrm{and} \mathrm{thus} \mathrm{requires}$ considerable attention for development of water resources and prevention of soil erosion. Changing climate in Himalayas is causing extreme events like landslides, glacial lake outburst floods etc. which has led to increase in disasters and is affecting lives of residents. Rural inhabitants of high hills in Himalayas are facing problem of fresh water owing to steep slopes, deforestation and poor water management practices.

Uttarakhand located in Himalayas in northern India has about $86 \%$ of its area under forests, wastelands and a small portion of about $14 \%$ is available for practicing agriculture [4] which is mostly rain fed. Rainfall statistics indicate wide variation in annual rainfall in state with average maximum annual rainfall of $2.426 \mathrm{~m}$ in Champawat to lowest average annual rainfall $0.406 \mathrm{~m}$ in Haridwar [5]. Uttarakhand is facing problem of pollution in its water resources as well as scarcity of water in several areas. Villagers in several mountainous regions especially women have to go long distances to fetch water in addition to taking care of agriculture, livestock and children etc. [6]. Owing to sufficient rainfall in its various districts, rainwater harvesting can serve as a major water resource during dry periods. It will also be useful in recharging 
ground water which is fast depleting at many places. Innovative and involved approach is required to meet water demands after assessment of available water resources.

\section{Description of Devasthal Observatory}

\subsection{Location and Infrastructure}

Devasthal observatory of Aryabhatta Research Institute of Observational Sciences (ARIES) is located in Nainital district of Uttarakhand, India (Fig. 1(a)). It is emerging as an important astronomical site in Central Himalayas with setup of three prominent telescopes at its top, supported by necessary infrastructure and guest house etc. (Fig. 1(b)). Devasthal site was shortlisted after surveying various places in Central Himalayan range using meteorological equipment's [7]. Located at a prime geographical location (29 $21^{\prime} \mathrm{N}$; $79^{\circ} 41^{\prime} \mathrm{E}$ ), observatory is well known for India's largest $3.6 \mathrm{~m}$ optical telescope with active optics which was activated remotely in 2016 by Indian and Belgian Prime Ministers. A $1.3 \mathrm{~m}$ Devasthal fast optical telescope [8] with unique roll-off roof [9] was earlier made operational at the site. A $4 \mathrm{~m}$ International Liquid Mirror Telescope (ILMT) containing telescope structure, dish, air bearing, drive system and optical corrector etc. has also been installed at site [10]. Site offers dark skies with sub-arc second seeing capabilities and has potential for exploration of various atmospheric measurements. Further, few astronomical and atmospheric instruments are being planned at site. Planning for science centre, mechanical laboratory, electronics laboratory cum office, hostel block and canteen has been carried out and their construction is going to start shortly at site.

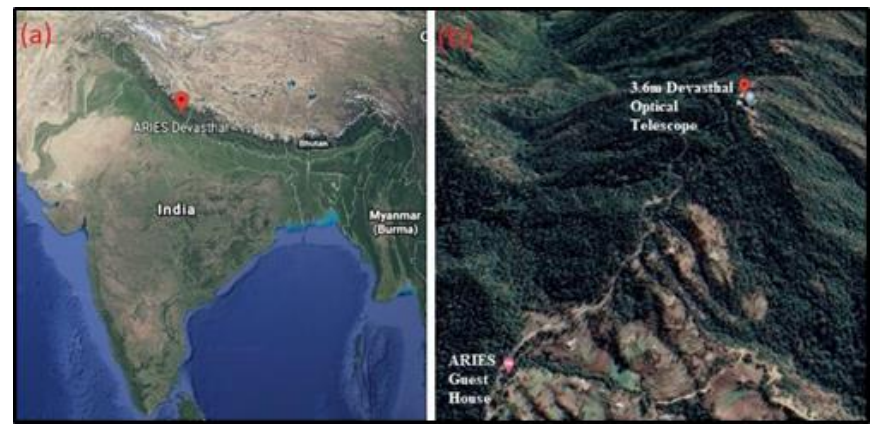

Fig. 1 (a) Location of ARIES Devasthal observatory in India. (b) Satellite view of Devasthal site from guest house to $3.6 \mathrm{~m}$ Devasthal optical telescope at top (Source: earth.google.com).

\subsection{Water Security Assessment}

Devasthal observatory is equipped with a guest house and a prefabricated residential structure at base camp which are well connected with about $1,500 \mathrm{~m}$ long metalled road to state highway for accommodating astronomers, visitors and staff etc. Further, road of about 1,500 $\mathrm{m}$ from base camp leads to the three telescope buildings at the hill top. Most of the scientific and technical activities related to telescopes take place in these buildings. Presently, bore well is the only source of fresh water at site and has served a long way in meeting the water demands at site. It provides good quality water as stored water filters in ground during its movement through the soil. Water from existing bore well is stored in a tank at base camp from where it is distributed to various tanks of buildings at site. Water is required at basecamp for drinking, washrooms and kitchen etc. The average water output from bore well is presently about 2.8 $\mathrm{m}^{3}$ per day amounting to about $84 \mathrm{~m}^{3}$ per month. Water output from bore well is slowly declining from the last few years and causing scarcity of water at site with increasing demand. It is observed that amount of rainfall is decreasing in Central Himalayas [11] and also at Devasthal site since past few years. Present water needs are met through an existing bore well at site but scarcity of water is felt during summers and in periods of multiple activities at site.

\subsection{Estimation of Rainfall}

Precipitation generally increases with altitude and Devasthal site located at about $2,450 \mathrm{~m}$ above mean sea level receives sufficient annual rainfall due to two major atmospheric circulations. Circulation during months of June to September is through south - west monsoon winds while western disturbances account for most of the rainfall during winter months starting from December to March. Rainfall data for 21 years (1998 to 2019) was accessed from Tropical Rainfall Measuring Mission (TRMM) [12] and is plotted in Fig. 2. The mean annual rainfall was estimated around $1.451 \mathrm{~m}$ (dotted red line) but most of the water runs off and goes unutilized due to mountainous terrains at Devasthal site.

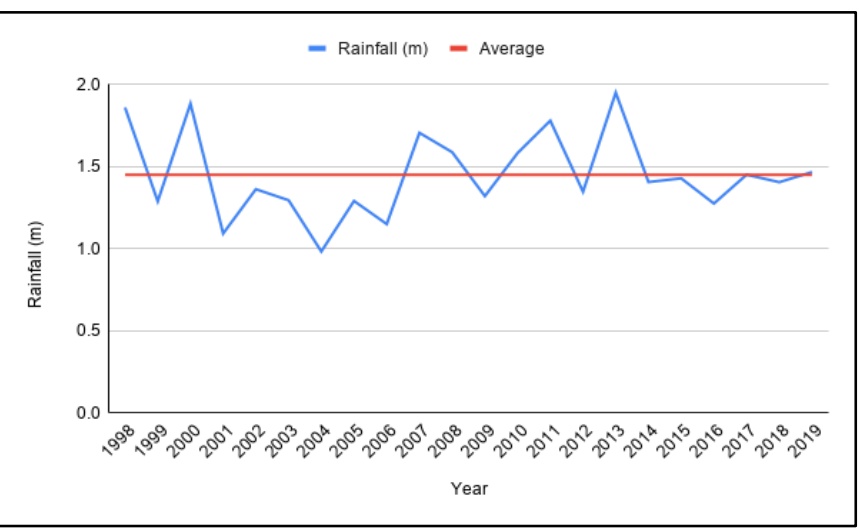

Fig. 2 Annual rainfall at site (1998-2019).

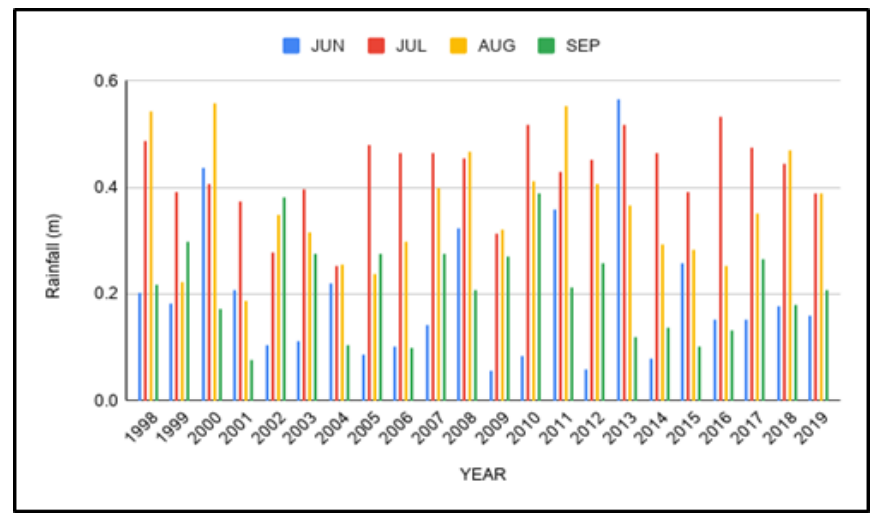

Fig. 3 Rainfall from June to Sept (1998-2019) 
Rainfall from 1998 to 2019 was maximum during months of June to September (Fig. 3) and account for about $79 \%$ of the annual rainfall. This period witnesses maximum water runoff and soil erosion at site.

\subsection{Necessity of Rainwater Harvesting}

The consumption of water at site was studied by taking in to account the average number of individuals residing or working at site along with their per capita water consumption pattern. Base camp residential set-up at observatory requires water for an average of about 20 persons such as astronomers, engineers, technical staff, canteen staff and security guards etc. The assessment of water requirements at base camp gives about 0.1 $\mathrm{m}^{3}$ per head per day making an average requirement of $60 \mathrm{~m}^{3}$ per month. Telescope buildings at top also have a requirement of about 20 persons for performing various activities related to three telescopes. Assessment of average water consumption pattern at telescope site and as per Indian standard code [13], the consumption for office is about $0.045 \mathrm{~m}^{3}$ of water per person per day. Thus requirement of water per month at three telescope buildings on top for 20 persons comes $27 \mathrm{~m}^{3}$ per month. Combined average monthly water demand of base camp and three telescope buildings amounts to about $87 \mathrm{~m}^{3}$ which is barely met by bore well supply of $84 \mathrm{~m}^{3}$ at site in normal conditions. Thus existing water supply through sole bore well is quite strained and needs alternative water supply to meet upcoming demands. Presently increase in number of persons and activities causes water shortages at site which will escalate as more infrastructure and activities come up in near future along with changing consumption patterns. Alternative sources of water are required at site to reduce complete dependence on sole ground water resource and meet rising demand at site. Additional deep ground water resources at site can be searched but that will involve heavy investment in rocky terrain and will become deficient over time with fall in water table. Assessment of mean annual rainfall at the site from 1998 to 2019 indicate that rainwater harvesting can be a good source of water supply for meeting the water demands at site. Remote location of site and absence of community piped water network make rainwater harvesting as the most reliable solution for supporting expanding infrastructure and increase in activities at site to attain self-sufficiency. Implementation of rainwater harvesting will reduce runoff, prevent soil erosion, supplement the ground water storage, improve quality of ground water and ensure long-term availability of water at site to meet current and upcoming demands. Rainwater harvesting techniques at site are planned in a phased manner to meet growing demands and support emergency conditions. Rain water as an alternative water source will serve as a substitute and back-up during dry periods. Collection of rainwater will reduce the burden of pumping ground water from base camp to top of site and enhance the supply of water. Harvested rainwater will remain available at top of site for telescope buildings during emergency conditions of forest fires which are quite common in hilly terrains. Water harvesting will also generate supplementary water management opportunities at site and provide positive stimulus to the environment. Efforts are planned to capture surface run-off for harvesting rainfall water in to the ground for restoring the health of existing bore well at site. Water harvesting initiatives in long run will also provide water supply for upcoming construction works, artificial recharge of ground water and horticulture activities etc. at the site. Few rainwater harvesting methodologies that are planned at Devasthal site to sustain present and future water requirements are briefed in the details what follows.

\section{Rainwater Harvesting Methodology}

Rainwater harvesting is a very effective technique of water conservation. Rainwater can be collected and stored for meeting various water requirements [14]. It involves management for water collection and its storage at surface or in aquifer underneath to support human and plant requirements [15]. Rainwater harvesting can be carried out by different types. Rainwater can be collected from rooftop, land surface or through watersheds. Collected rainwater can be used to rejuvenate ground water aquifers or fill water storage tanks. The stored water in tanks is then pumped through a network of pipes for distribution to various places. Use of this technique in hills will not only meet the increasing water demands but also reduce the overall water treatment and distribution costs. Rainwater is abundant and clean source of water that can be utilized at Devasthal observatory. Investment in rooftop rainwater harvesting will enable observatory in meeting its water demands along with environmental sustainability. Rooftop rainwater harvesting once implemented at site will further require minimal maintenance, least manpower resources and will be economical than pumping of ground water from bore well. Rainwater as an alternate source of water at observatory will considerably reduce dependency on existing bore well to meet water demands at site. Owing to pristine geographical location of site and absence of industrial activities, rainwater will provide good quality water at site and can be used for both potable and non-potable requirements.

\subsection{Recharge of existing bore well}

Groundwater accounts for $97 \%$ of global fresh water resources and is a vital drinking water source in most parts of the world owing to its quality [16]. Soil cleans water as it passes through it during rainfall and holds it in aquifers that serve as an important source of ground water during dry period. Recharging of ground water in steep terrain is difficult owing to heavy runoff. Recharging of existing bore well at site is an important activity for sustainability and will be carried out broadly in three stages. Initially, digging of pits in the path of surface runoff around the bore well for its natural recharge are planned. Some of these pits will also be filled with suitably selected boulders at bottom, gravel in middle and coarse sand on top in graded form for artificial recharge and to deposit silt that will come from surface runoff. As natural recharge is mostly during rainy months, artificial recharge will be used to supplement it during post monsoon period. Buildings planned in near future are quite close to bore well area and will be 
constructed with provision for rainwater harvesting. The overflow water from rooftop rainwater harvesting of these upcoming buildings will be directed towards the strategically located recharge pits for their artificial recharge. This recharge will replenish depleted water in the aquifers. In second stage, contour trenches will be dug perpendicular to the hill slope near the bore well so that it can cause more seepage of surface runoff water in to the aquifers. In third stage, plants and trees that support holding of moisture will be planted near bore well area for supporting natural recharge and prevention of soil erosion. Recharging of existing bore well in this way will give good quality water and will support the environment and ecosystems.

\subsection{Design of Rooftop Rainwater Harvesting System}

Rooftop rainwater harvesting systems are quite efficient and are commonly employed for harvesting rainwater [17]. They are most popular owing to their supply of good quality water. Roof materials play a vital role in rooftop rainwater harvesting system. Roof should be hard, non-toxic, away from trees and easy to maintain. Water is collected from roof in to the gutters. Wire meshes are fitted at end of gutters to trap leaves and other dust particles etc. A first flush device or a detachable section of down pipe to flush initial rainwater is installed in downpipes connected to gutters. Foremost, requirement to set up a rooftop rain water harvesting system is availability of suitable roof catchment which is free from hindrances of trees etc. Setup of roof top rain water harvesting system also requires availability of space for storing collected water and its distribution to required places.

Buildings for the three telescopes at top of site have sloping roofs which can be used for collecting rain water. Three telescope buildings at observatory with respective moving roof sections are depicted in Fig. 4 (a) to 4 (c).

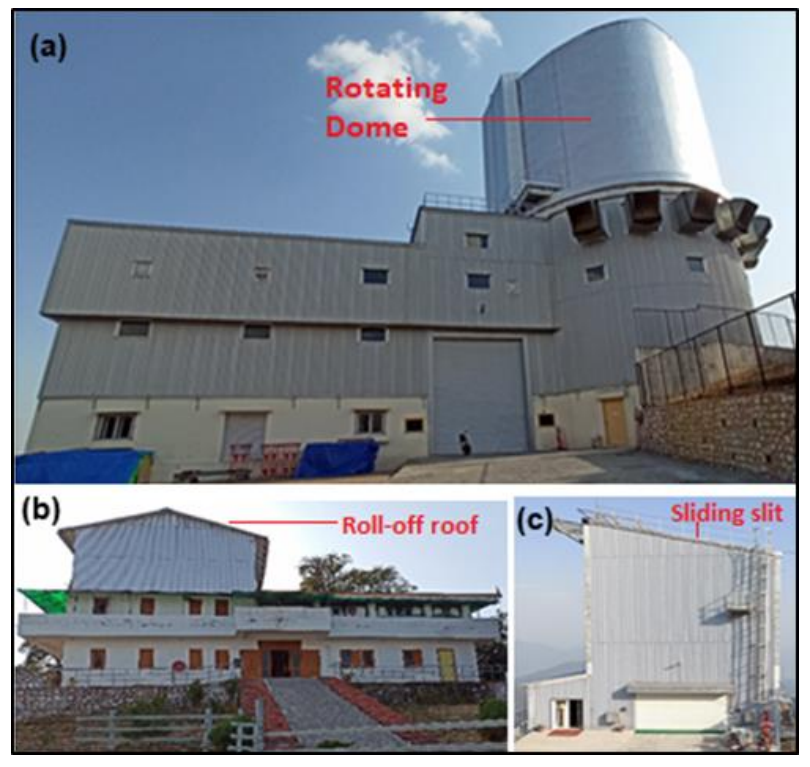

Fig. 4 Telescope buildings at Devasthal Observatory with respective moving roof sections (a) $3.6 \mathrm{~m}$ Telescope building (b) $1.3 \mathrm{~m}$ Telescope building (c) ILMT building.
The feasibility study of telescope buildings and present water distribution network was carried out for implementing rooftop rainwater harvesting scheme and it was found that:

- The $3.6 \mathrm{~m}$ telescope building has dome that rotates during telescope observations so its fixed part i.e. extension building meant for aluminizing related activities can be used as catchment for collecting rainwater.

- The $1.3 \mathrm{~m}$ telescope building has a roll-off roof that completely rolls-off for the observations so it doesn't provide a viable solution.

- The roof of ILMT building is fixed but it has a sliding slit in its roof for telescope viewing and was thus not considered.

- The extension building of 3.6m telescope has an advantage that it has large collection area compared to other two telescope buildings. Its sloping roof as catchment will yield sufficient water required to meet demand for telescope buildings.

- Rainwater harvesting implementation near hill top will considerably lower the burden on existing bore well and its pumping system apart from creating an alternate water resource at site.

- Pumping of water from bore well at base camp to top of hill having telescope buildings requires considerable expenses and effort in terms of electricity and manpower apart from increased maintenance cost of equipment's and piping.

- Bore well at base camp presently fills the water in storage tank located on a nearby ridge from where water is distributed to the buildings at the base camp through gravity feed system owing to sufficient height difference between them. Implementation of rainwater harvesting at hill top will mainly require power for pumping of water over short distance till the storage tank only.

- Rainwater harvesting will significantly reduce dependence of telescope buildings on supply of bore well water.

- A buffer stock of water will be available at telescope site to meet emergency conditions of forest fires and breakdowns in existing water distribution system.

To begin with, a scheme of rainwater harvesting system utilizing rooftop of extension building of $3.6 \mathrm{~m}$ telescope enclosure as catchment is planned for the site. Estimation of rooftop rainwater harvesting potential of $3.6 \mathrm{~m}$ telescope extension building is carried out and accordingly suitable rainwater harvesting system is designed to supplement the site demands.

Design of rainwater harvesting system requires detailed planning for its various constituents and associated equipment's to get good quality water. Rooftop rainwater harvesting design using rooftop of extension building of $3.6 \mathrm{~m}$ telescope enclosure will consist of five major components viz. catchment, gutters and down pipes, first flush system, filter units and storage tank. A pumping unit for distributing water 
to different buildings will be connected to the storage tank. 3.6 $\mathrm{m}$ Telescope building showing extension building is depicted in Fig. 5 (a). Schematic of rooftop rainwater harvesting system design using extension building of $3.6 \mathrm{~m}$ telescope enclosure is represented in Figure 5 (b) and is briefed in the details what follows.

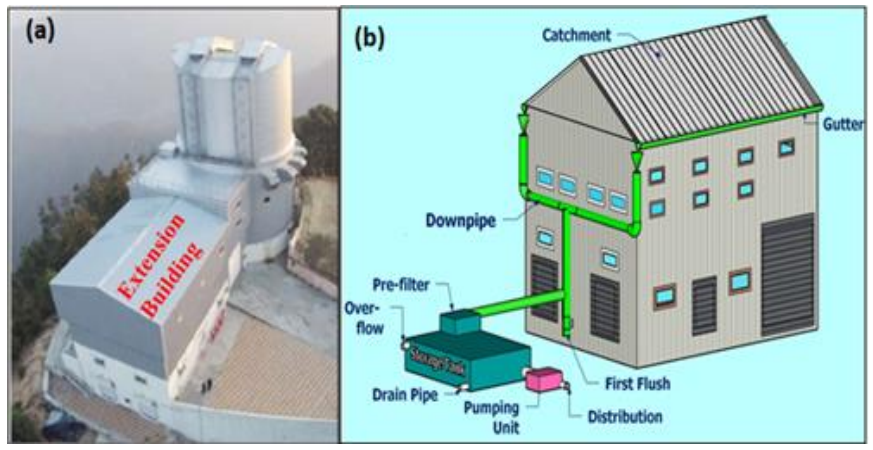

Fig. 5 (a) $3.6 \mathrm{~m}$ Telescope building showing extension building. (b) Schematic of rooftop rainwater harvesting system using extension building.

\subsubsection{Catchment}

For collecting rainwater at site, it needs to come in contact with a predefined area called catchment. The quality and quantity of harvested rainwater depends on the type, surface finish size, slope and maintenance etc. of the roof [18]. Roof should be able to accumulate water in the storage tank with available rainfall at the site. Normally, roofs made of concrete and sheets are used as catchments for collecting rainwater.

Table 1

Rainwater Collection Potential for Extension Building of $3.6 \mathrm{~m}$

Telescope Enclosure

\begin{tabular}{|c|c|c|c|c|}
\hline Month & $\begin{array}{c}\text { Average } \\
\text { rainfall } \\
(\mathbf{A}) \\
(\mathbf{m})\end{array}$ & $\begin{array}{c}\text { Collection } \\
\text { Area } \\
(\mathbf{B}) \\
\left(\mathbf{m}^{\mathbf{2}}\right)\end{array}$ & $\begin{array}{c}\text { Available } \\
\text { water } \\
(\mathbf{C = A \times B}) \\
\left(\mathbf{m}^{\mathbf{3}}\right)\end{array}$ & $\begin{array}{c}\text { Collection } \\
\text { Potential } \\
(\mathbf{D = C \times 0 . 9 )} \\
\left(\mathbf{m}^{\mathbf{3}}\right)\end{array}$ \\
\hline JAN & 0.036 & 300 & 10.8 & 9.72 \\
\hline FEB & 0.051 & 300 & 15.3 & 13.77 \\
\hline MAR & 0.031 & 300 & 9.3 & 8.37 \\
\hline APR & 0.025 & 300 & 7.5 & 6.75 \\
\hline MAY & 0.052 & 300 & 15.6 & 14.04 \\
\hline JUN & 0.193 & 300 & 57.9 & 52.11 \\
\hline JUL & 0.428 & 300 & 128.4 & 115.56 \\
\hline AUG & 0.362 & 300 & 108.6 & 97.74 \\
\hline SEP & 0.213 & 300 & 63.9 & 57.51 \\
\hline OCT & 0.047 & 300 & 14.1 & 12.69 \\
\hline NOV & 0.003 & 300 & 0.9 & 0.81 \\
\hline DEC & 0.01 & 300 & 3.0 & 2.70 \\
\hline & & & Total & $\mathbf{3 9 1 . 7 7}$ \\
\hline
\end{tabular}

Extension building of $3.6 \mathrm{~m}$ telescope enclosure with roof collection area of about $300 \mathrm{~m}^{2}$ is planned to be used as catchment area for collecting rainwater. Product of average rainfall data for each month in a year from 1998 to 2019 with collection area gives available water that can be collected from the specified area. Different types of roofs have different runoff coefficients ranging from 0.6 for flat cement roof to greater than 0.9 for galvanized iron sheets [19-20]. Sloping roofs have higher runoff coefficient and are thus more efficient in collection of rainwater than flat roofs. The sloping roof of extension building has galvalume (aluminium-zinc alloy) coated profiled steel sheets for which a runoff coefficient of 0.9 is considered and accordingly the collection potential of roof for each month using average of monthly rainfall data of TRMM from 1998 to 2019 has been calculated and tabulated in Table 1. The total collection potential for the whole year comes around $392 \mathrm{~m}^{3}$ per year.

\subsubsection{Gutters and down pipes}

Gutters and downpipes together constitute conveyance system to effectively transport collected rainwater from roof surface to the filter before storing in tank. Water can be routed easily using gravity through sloping roof in to the gutters. Gutters collect the rainwater falling on roof and direct them using down/drain pipes for storing in storage tanks. Sturdy system of chemically inert/non-toxic gutters and drain pipes is required owing to high wind and rainfall periods at Devasthal site. About $0.3 \mathrm{~m}$ half round gutters will be used for collecting rainwater as they are easy to clean and allow a faster flow of water through their curved base. Gutter will be provided with a slope of 0.5 to $1 \%$ and an anchoring system using brackets to hold on to the roof of extension building of telescope. Slope provided in gutters will ensure smooth flow of water, prevention of debris and keeping them dry between consecutive rainfall events. Water from gutters will be transferred to down pipes that will be connected to filter over storage tank. A mesh type screen filter at inlet of down pipe will be fitted to prevent entry of deposits etc. into the down pipe. This will be useful in reducing blockage in distribution pipes and also decrease their maintenance cost.

\subsubsection{First flush system}

Rooftop of extension building may gather debris during dry period and it gets washed off from its surface during rainfall over it. Flushing water prevents entry of debris into the storage tank and subsequently prevents blockages in pump components. First flush system will be used to drain off first part of rainwater and prevent entry of undesirable materials such as leaves, twigs, sand, bird droppings etc. in filter and storage tank. First flush system will consist of a vertical pipe connected to the down pipe with a valve at its end. During rainfall as the water comes from the roof to gutters, it will drain from down pipe into the first flush pipe. The valve at the first flush pipe will drain the initial dirty water after which it will be closed so that water is diverted to pre-filter over the storage 
tank. Most of the bacteria in organic matter that collects at rooftop are washed away as it is flushed at beginning of water collection. This first flush system will help to improve the quality of collected rainwater by keeping the contaminants and pollutants out of the tanks, extend the life of pumps and reduce tank maintenance.

\subsubsection{Filter units}

Collected water from rooftop is contaminated and requires treatment to enhance its quality. Prevention of water from microorganisms such as bacteria and other contaminants require planning appropriate treatment of the water. Treatment can be done in various steps from collection to supply in the system. Treatment significantly decreases harmful contaminants etc. that affect color and odour of water. Treatment of rainwater harvesting at site will consist of natural filtration chamber over storage tank and filters inside building. Natural filter also known as sand gravel filter will be constructed with brick masonry. It will consist of different chambers filled with sand, gravel and pebbles separated by wire mesh. It is useful for removing dust, silt and organic matter from water. Filtration will ensure removal of unwanted particles before storage and prevent contamination of stored water. Building inline filters will be ultra violet or reverse osmosis base which will be used for drinking water.

\subsubsection{Storage tank}

To meet water demands at the observatory storage of water for dry months or period of intermittent rains needs to be formulated. Storage tank is the most expensive component in rainwater harvesting system. Tanks made up of different materials are used for storing water based on climatic conditions, availability, space constraints, aesthetics and cost etc. Tanks made of plastic (polyethylene), metal, fiber glass, ferro-cement and concrete are commonly used for storage in rainwater harvesting systems. Owing to extreme climatic conditions at Devasthal site, covered concrete storage tank with fixtures for drawing of water and provision for periodic cleaning will be constructed at site. Concrete water tanks are durable, long lasting and can be constructed below or above the ground. Building the storage tank underground escalates the construction costs in hills due to rugged mountainous terrain. Due to water loss in first flush and filtration, the water harvesting system will have an efficiency of about $90 \%$. So calculated collection potential of about $392 \mathrm{~m}^{3}$ per year will further decrease to about $352.8 \mathrm{~m}^{3}$ per year.

A minimum water tank storage capacity to feed the users during dry period is required to be considered. Volume of water that can be stored by collection from rainwater harvesting should be equal or more than the water demand for three telescope buildings at site. Water demand of $27 \mathrm{~m}^{3}$ per month at telescope buildings is require to be fulfilled. Cumulative supply and cumulative demand for all months have been tabulated and their difference provides water storage requirement at site (Table 2).
Table 2

Estimation of Water Storage Requirement from Cumulative Supply and Demand

\begin{tabular}{|c|c|c|c|c|c|}
\hline Month & $\begin{array}{c}\text { Collection } \\
\text { Potential } \\
(\mathbf{D} \times \mathbf{0 . 9}) \\
\left(\mathbf{m}^{\mathbf{3}}\right)\end{array}$ & $\begin{array}{c}\text { Cumul } \\
\text { ative } \\
\text { Supply } \\
\left(\mathbf{m}^{\mathbf{3}}\right)\end{array}$ & $\begin{array}{c}\text { Water } \\
\text { Demand } \\
\mathbf{/ m o n t h} \\
\left(\mathbf{m}^{\mathbf{3}}\right)\end{array}$ & $\begin{array}{l}\text { Cumul } \\
\text { ative } \\
\text { Demand } \\
\left(\mathbf{m}^{\mathbf{3}}\right)\end{array}$ & $\begin{array}{c}\text { Storage } \\
\text { Requir } \\
\mathbf{e m e n t} \\
\left(\mathbf{m}^{\mathbf{3}}\right)\end{array}$ \\
\hline JUN & 46.90 & 46.90 & 27 & 27 & 19.90 \\
\hline JUL & 104.00 & 150.90 & 27 & 54 & 96.90 \\
\hline AUG & 87.97 & 238.87 & 27 & 81 & 157.87 \\
\hline OCT & 11.42 & 302.05 & 27 & 135 & 167.05 \\
\hline NOV & 0.73 & 302.78 & 27 & 162 & 140.78 \\
\hline DEC & 2.43 & 305.21 & 27 & 189 & 116.21 \\
\hline JAN & 8.75 & 313.96 & 27 & 216 & 97.96 \\
\hline FEB & 12.39 & 326.35 & 27 & 243 & 83.35 \\
\hline MAR & 7.53 & 333.88 & 27 & 270 & 63.88 \\
\hline APR & 6.08 & 339.96 & 27 & 297 & 42.96 \\
\hline MAY & 12.64 & 352.59 & 27 & 324 & 28.59 \\
\hline
\end{tabular}

Required capacity of storage tank can be estimated by the greatest difference between the cumulative supply of rainwater and water demand [21] as depicted in Fig. 6. As per table and plotted graph, it occurs in the month of September with storage requirement of $182.63 \mathrm{~m}^{3}$.Analysis of rooftop rainwater harvesting using extension building of $3.6 \mathrm{~m}$ telescope enclosure as catchment indicates that its implementation will yield a huge quantity of water in September to supplement water demands during the period of little and intermittent rainfall at site. Existing storage for three telescope buildings on top at site is around $15 \mathrm{~m}^{3}$ so additional storage capacity of about $165 \mathrm{~m}^{3}$ is presently proposed around the $3.6 \mathrm{~m}$ telescope building.

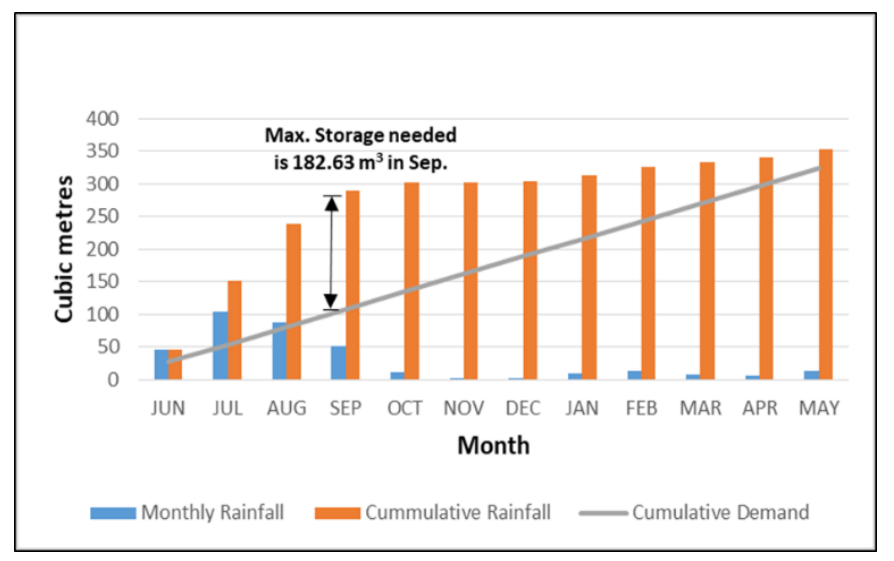

Fig. 6 Estimation of water storage requirement from greatest difference between the cumulative supply of rainwater and cumulative demand. 
Storage tank will be equipped with level sensor and markings to indicate amount of water stored in it. Water supply from bore well through existing piping network at site will serve as a backup for meeting shortages due to fluctuations in demand and rainfall at site. A drain pipe will be provided at the base of the tank to transfer water for cleaning or flushing of tank periodically to maintain good quality of water supply. Water in tanks will also be prevented from contamination by outside waste water etc. An overflow pipe will be provided near the top of tank so that during overflow the water can be used for natural recharge. Tank will be provided with a manhole of $0.50 \mathrm{~m} \times 0.50 \mathrm{~m}$ size with cover for its maintenance activities.

Judicious management of water is planned to conserve the available water at site. Regulation of water extraction from the storage tank will be carried out to optimize water utilization so that it can last throughout the dry season. Smart water management systems will be implemented through sensor based technologies for water conservation. Distribution system consisting of pumps and pipes will be connected to tank for distribution of water to the three telescope buildings. Automatic water tank sensors will be employed to switch on and off the pump when water in overhead tanks of buildings go to low and full levels. This will maintain the water levels in overhead tanks without requirement of manpower.

Most of the piping will be underground and with suitable insulation to avoid freezing of water during winters. Proper color coding of water distribution pipes and insulation over them will be carried out so that underground pipes can be easily identified during excavations and they can also be easily recognized inside the buildings. Valves etc. will also be labelled for ease of identification and operation. Water conservation habits will be encouraged at site. This will involve keeping check on all water faucets and preventing leakages. Water saving washrooms will be developed with installation of faucet aerators and two stage flush systems etc. that will use less water for the same function. Rooftop rainwater harvesting scheme will support the manpower involved in various observational and maintenance activities of three telescopes at top of site.

\section{Smart Water management with IoT}

Water management at site involves monitoring of various parameters of water such as its level, quality, prevention of leakages and taking suitable timely decisions for distribution of water to meet demand. Monitoring of water quantity and quality requires considerable human effort. IoT serves as an effective tool for water management and monitoring of various parameters. Water management at telescope site is planned with smart systems based on IoT for monitoring consumption, water quality and regulation of water for its conservation. Technology will be employed to control the whole water supply chain from collection of rainwater in storage tank to its distribution to three buildings at site. IoT will employ sensors, communication network and data processing. Variety of sensors at different locations will be employed for smart water management. Data received from sensors will also be used for detecting water quantity and quality issues so that corrective actions can be performed. A schematic of smart rainwater management system is shown in Fig. 7.

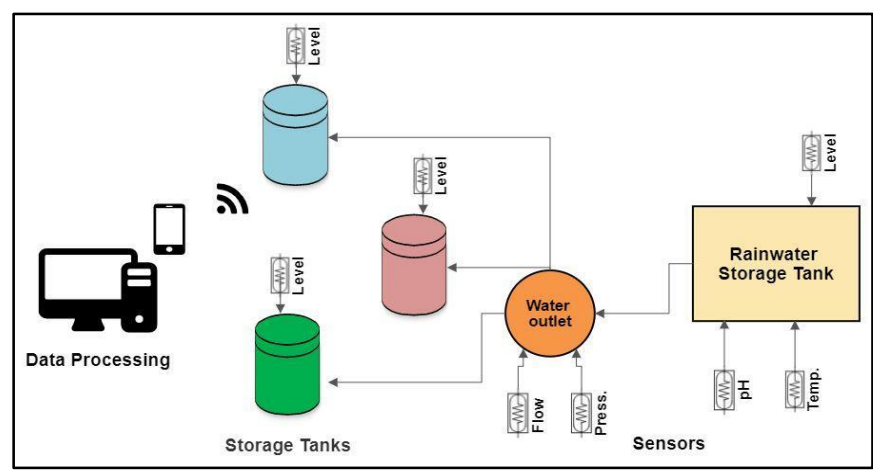

Fig. 7 Schematic of smart rainwater management system.

Sensors will monitor quality and quantity of rain water collected in tank after its treatment. Rainwater storage tank will be equipped with level sensor to update on the quantity of water available in it. Storage in concrete cisterns can increase $\mathrm{pH}$ (potential of hydrogen) [22], so a pH sensor will be fitted in the tank to monitor the same. A temperature sensor will be fitted in the storage tank to give its real-time measurements so that corrective action can be taken during winters if water starts freezing. Pressure sensors will be provided in water outlet to monitor leakages in the piping network. Flow rate sensor will be fitted in the water outlet to measure the consumption of water. Data of high consumption of water during non-working hours indicates presence of leaks in the system. High flow rate measurements through sensors will send alert indicating possibility of leakages in the system. IoT switch will be installed on the pumping unit distributing water to the overhead tanks in the three buildings. This will give flexibility of switching on the pumping unit through internet connectivity from any place in the Devasthal campus at any time. The level of water in the overhead tanks of buildings will be sensed through water level sensor which will be connected to IoT pump controller over internet through $\mathrm{Wi}-\mathrm{Fi}$. IoT network based on feedback from sensors will be used to manage water in tanks on different buildings so that timely corrective actions can be taken to meet demand. Smart meters will be employed for the three buildings to monitor their water consumptions. Data collected over IoT enabled water sensors will be used to keep check on the quality, temperature and pressure of water. Water will be supplied to each building using smart IoT based water control system. Smart distribution system will ensure regulated supply of water to the endpoints and prevent wastage of water. Data will be further made accessible in real time over computer and smartphone through wireless network and analyzed with suitable software platform to reduce human intervention over time. Design of IoT based network will be kept simple but flexible with low maintenance costs.

Rainwater harvesting with IoT based network will be the first of its kind to be undertaken at Devasthal observatory to make it self-sufficient in meeting its water demands. It will also impart learning for upcoming infrastructure planned at 
site. IOT based real time monitoring at remote site will be beneficial to detect water related issues so that they can be addressed well in time. It will provide a network for exchange of water related data at site that will be useful for maintenance of piping network and pumps in the system. IoT based smart water management will serve as an efficient technique at site and will be useful in predicting the amount of water required at different buildings. Its implementation will increase productivity and lower operating and maintenance costs at site. Water management using IoT will serve as an efficient tool to save the water for vital activities, avoid water crises and revolutionize water management at site in the future.

\section{Conclusions}

Estimation of water supply and consumption at remote astronomical site of Devasthal was carried out. Rainfall data for the site was studied and use of rainwater for natural and artificial recharging of existing bore well has been worked out. An initiative towards self-reliance of three telescope buildings at hill top on site is planned by designing a rooftop rainwater harvesting scheme using one of the telescope buildings. The $3.6 \mathrm{~m}$ telescope extension building was selected as the requisite catchment area after undertaking feasibility study of three telescope buildings and present water distribution network for implementing rooftop rainwater harvesting scheme. Estimation of storage requirement for meeting demand of water at telescope site during dry season indicated the amount of additional storage capacity that needs to be planned at site. Recharging of ground water and rooftop rainwater harvesting at site for existing and upcoming infrastructure seem to be the best suited and economical measure for water conservation at site. It will prevent decrease in ground water level at base camp, improve ground water quality and provide rainwater for sustainable development of the site. Rainwater harvesting initiative at astronomical site of ARIES will provide water reserves that will be useful both in normal and emergency situations. Source of water will become available to buildings at hill top and reduce overall running and maintenance costs.

Water harvesting technologies are quite flexible and will be implemented in phased manner at observatory. Userfriendly IoT technology for water management will provide real-time efficient monitoring through sensors and minimize manpower requirements at remote site. Water harvesting techniques will go a long way in restoring the water balance and supporting upcoming and future endeavors at observatory. Rainwater harvesting will be further extended to other buildings at site and modular design approach will be adopted for its expansion in future. Implementation of rainwater harvesting at Devasthal observatory will also encourage local inhabitants and other observatories at remote locations to follow it in a systematic and fruitful manner to meet their water demands. Important outcome of this work will be implementation and transition to sustainable technologies for water security at site. It will serve as an ideal case study for expansion of sustainable technologies for inhabitants and nearby communities.

\section{Acknowledgements}

Author would like to express his sincere gratitude to Director, ARIES for his constant encouragement. Author is also grateful to Dr. Wahab Uddin, Dr. Ashish Kumar, Mr. Ramesh Raskar and to all those who provided help for carrying out this work. Author is thankful to NASA for their valuable rainfall data from TRMM website.

\section{References}

[1] P. Tiwari, "Land Use Changes in Himalaya and Their Impacts on Environment, Society and Economy: A Study of the Lake Region in Kumaon Himalaya, India”, Advances in atmospheric sciences, 25(6), 2008, 1029-1042 doi:10.1007/s00376-008-1029-x.

[2] M. A. Kawosa, Remote Sensing of the Himalaya (Dehradun: Natraj Publishers, 1988). ISBN: 8185019126.

[3] D. Alford, Hydrological Aspects of the Himalayan Region, (Kathmandu, Nepal : International centre for integrated mountain development, 1992). ISBN: 92-9115-399-0.

[4] M. Chhimwal, R. K. Pandey \& R. K. Srivastava, "Status of agriculture and horticulture farming in the hill state of India-Uttarakhand", Journal of Pharmacognosy and Phytochemistry , 8(4), 2019,1626-1631.

[5] V. Kumar, Shanu \& Jahangeer, "Statistical distribution of rainfall in Uttarakhand India", Applied Water Science, 7(8), 2017, 4765-4776 doi: 10.1007/s 13201-017-0586-5 [6]

B. Joshi, "Recent Trends of Rural Out-migration and its Socio-economic and Environmental Impacts in Uttarakhand Himalaya", Journal of Urban and Regional Studies on Contemporary India, 4(2), 2018, 1-14. doi: $10.15027 / 45581$

[7] R. Sagar, C. S. Stalin, A. K. Pandey, W. Uddin, V. Mohan, B. B. Sanwal, S. K. Gupta, R. K. S. Yadav, A. K. Durgapal, S. Joshi, B. Kumar, A. C. Gupta, Y. C. Joshi, J. B. Srivastava, U. S. Chaubey, M. Singh, P. Pant \& K. G. Gupta, "Evaluation of Devasthal site for optical astronomical observations", Astronomy and Astrophysics Supplement Series, 144, 2000, 349-362. doi: 10.1051/aas:2000213.

[8] R. Sagar, A. Omar, B. Kumar, M. Gopinathan, S. B. Pandey, T. Bangia, J. Pant, V. Shukla \& S. Yadava, "The new 130-cm Optical telescope at Devasthal Nainital", Current Science, 101, 2011, 1020-1023.

[9] T. Bangia "Unique Roll-Off Roof for Housing $1.3 \mathrm{~m}$ Telescope at Devasthal Nainital", Journal of The Institution of Engineers (India): Series C ,98, 2017, 359-

366. doi: 10.1007/s40032-016-0242-0

[10] J. Surdej, P. Hickson, E. Borra, J. P. Swings, S. Habraken, T. Akhunov, P. Bartczak, H. Chand, M. De Becker, L. Delchambre, F. Finet, B. Kumar, A. Pandey, A. Pospieszalska, B. Pradhan, R. Sagar, O. Wertz, P. De Cat, S. Denis, J. de Ville, M. K. Jaiswar, P. Lampens, N. Nanjappa \& J. M. Tortolani, "The 4-m International Liquid Mirror Telescope", Bulletin de la Société Royale des Sciences de Liège, 87, 2018, 68-79. doi: 10.25518/00379565.7498

[11] L. N. Thakural, S. Kumar, S. K. Jain \& T. Ahmad, The Impact of Climate Change on Rainfall Variability: A 
Study in Central Himalayas; Climate Change Impacts, (Singapore : Springer, 2018). doi: 10.1007/978-981-105714-4_15.

[12] NASA Tropical Rainfall Measuring Mission (TRMM), TRMM (TMPA/3B43) Rainfall Estimate L3 1 month 0.25 degree x 0.25 degree V7 Greenbelt MD Goddard Earth Sciences Data and Information Services Center (GES DISC), 2011, Accessed: [06-12-2020] 10.5067/TRMM/TMPA/MONTH/7.

[13] Code of Basic Requirements for Water Supply, Drainage and Sanitation, 4th revision, IS 1172, (New Delhi: Bureau of Indian Standards, 1993 Reaffirmed 2007).

[14] J. Worm \& T. van Hattum, Rainwater harvesting for domestic use Ist ed. (Netherlands: Digigrafi Wageningen, 2006). ISBN: 90-8573-053-8.

[15] R. Kumar, D. Jhajharia, R. Dhura, S. Chand, M. Kumar \& R. M. Shukla, "Rainwater harvesting in north-western Himalayan region-A case study", Journal of soil and water Conservation, 11(4), 2012, 323-328.

[16] G. Howard, J. Bartram, S. Pedley, O. Schmoll, I. Chorus \& P. Berger, Groundwater and public health; Protecting Groundwater for Health: Managing the Quality of Drinking-water Sources, Ist ed., (UK : World Health Organization, IWA Publishing, 2006). ISBN: 924 1546689.
[17] C. A. Novak, E. Van Geisen \& K. M. DeBusk, Designing Rainwater Harvesting Systems: Integrating Rainwater into Building Systems (New Jersey: John Wiley \& Sons Inc, 2014). ISBN-10: 9781118410479.

[18] R. Farreny, T. Morales-Pinzón, A. Guisasola, C. Tayà, J. Rieradevall \& X. Gabarrell, "Roof selection for rainwater harvesting: Quantity and quality assessments in Spain", Water Research, 45(10), 2011, 3245-3254. doi: 10.1016/ j.watres. 2011. 03.036.

[19] A. Pacey \& A. Cullis, Rainwater harvesting: The collection of rainfall and runoff in rural areas. (London: Intermediate Technology Publications, 1986). ISBN : 0946688222.

[20] J. Jue \& T. T. Htwe, "Determination of Rainwater Harvesting System in Mindat District", International Journal of Scientific Engineering and Technology Research, 3(10), 2014, 1905-1911.

[21] O. Lade \& D. Oloke, "Assessment of Rainwater Harvesting Potential in Ibadan Nigeria", Environmental Engineering Research, 18(2), 2013, 91-94. doi: 10.4491/eer.2013. 18.2.091.

[22] C. Hart \& D. White, "Water quality and construction materials in rainwater catchments across Alaska", Journal of Environmental Engineering and Science 5, 2006, S19S25. doi:10.1139/s05-026. 